\title{
RELASI POLITIK DAN AGAMA DI TENGAH KETIDAKPASTIAN IDEOLOGI
}

\author{
Oleh:
}

Maskuri

Fakultas Tarbiyah IAI Ibrahimy

\begin{abstract}
:
Relation between religion and nation state is a term that often be a topic discuss in terms of political Islam, there is an opinion that the relationship between religion and the state are integrated as an entity, and the other say there is a mention that religion and the state it is only a mutualistic-symbiotic, in another context mentioned implementers. And the other side, the relationship between religion and the state is not at all related to each other that called secularist-liberalis. Religion should not intervene against the state, and vice versa. However, globalization makes politic loses its meaning as a tool in the struggle for the establishment of an ideal society. Thus, this paper is more emphasis on the relation between religion and the state in politic.
\end{abstract}

Key words: Relasi Politik, Agama, Negara, Dan Ideology Politik

\section{A. Pendahuluan}

\section{Manusia Sebagai Mahluk Sosial dan Politik}

Membahas dan mengkaji tentang politik hampir tidak pernah menemukan kata jemu. Membahas politik berarti membicarakan tabiat manusia sebagai mahluk social, yang satu sama lain saling memerlukan. Mengenai manusia sebagai mahluk sosial, Khaldun ${ }^{1}$ mengelompokkan menjadi dua, yaitu pertama, ideologi masyarakat yang tinggal disebuah

\footnotetext{
${ }^{1}$ Ibnu Khaldun dilahirkan di Tunisia pada permulaan bulan Ramadhan tahun $732 \mathrm{H}$, bertepatan dengan tanggal 27 Mei 1332 M. Beliau sering dikenal sebagai pemikir dan ilmuwan muslim yang mewarnai studi tentang sosiologi. Karyannya yang sangat terkenal, yaitu "Muqaddimah" telah banyak memberikan inspirasi bagi perkembangan studi ilmuilmu social, termasuk didalamnya ilmu politik. Ia sangat memperhatkan isntitusi-institusi social (misalnya ekonomi, politik) dan kaitan antara berbagai institusi dengan relasi social lainnya. Lihat ( Nanang Martono, "Sosiologi Perubahn Sosial”, Jakarta: RajaGrafindo Persada, 2012), 30. Dan George Ritzer dan Douglas J. Goodman, "Teori Sosiologi, terj. Nurhadi, Bantul: Kreasi Wacana, cet. Ke tujuh, 2011), hlm. 6
} 
pedesaan, hidup di pedalaman, primitive, dan mereka tinggal di daerah gurun. Kelompok inilah yang disebut sebagai ideologi masyarakat badawah atau badui. Kedua, masyarakat yang hidup di perkotaan yang telah memiliki peradaban, atau dalam istilah lain disebut sebagai "hadarah" atau masyarakat kota. Manusia dalam pandangan Ibnu Khaldun dan Abi Rabi' adalah mahluk yang tidak bisa hidup sendiri, membutuhkan bantuan orang lain untuk memenuhi kebutuhannya. Bila ingin survive maka ia harus melakukan interaksi social, sehingga membentuk suatu komunitas masyarakat dan ideologi sosial adalah sebuah keniscayaan². Dan komunitas tersebut adalah Negara.

Pembahasan pertama negara tidak bisa dipisahkan dengan pembahasan politik, karena politik dan Negara sesuatu yang integrate. Persoalannya adalah: ketika masuk pada kajian analisa tentang politik, maka banyak muncul berbagai macam definisi, asumsi, dan cara pandang, tergantung darimana seseorang melihat dunia politik. Ada yang menganggap bahwa politik itu identik dengan konflik, penuh kebohongan, penuh tipu daya, dan beragam kesan ideologi dialamatkan kepada pemaknaan politik. Menurut Firmanzah ${ }^{3}$, bahwa pandangan banyak pihak yang mengasumsikan politik sebagai tujuan adalah ketika pragmatism politik yang mengedepankan 'yang penting berkuasa'. Dorongan nafsu ingin berkuasa mengalahkan sikap bagaimana seharusnya kekuasaan itu digunakan untuk melakukan perubahan terhadap kebijakan public yang dianggap telah mengganggu ketentraman manusia. ${ }^{4}$ Karena itu, penting dikemukakan kajian akademik tentang politik yang merujuk pada beberapa pemikiran politik.

Plato (428-328 BC), sebagaimana dalam 'The Republic', memandang politik sebagai semua usaha dan aktivitas yang dilakukan oleh sekelompok masyarakat dalam membentuk tatanan masyarakat yang ideal, atau sebuah masyarakat yang kondisinya lebih baik dari kondisi sebelumnya. Sementara Aristoteles, dalam The Politic, mendefinisikan politik sebagai sesuatu yang ada dalam diri manusia itu sendiri, politik bukanlah sesuatu yang diciptakan dalam sebuah konsep. Atau dengan

\footnotetext{
${ }^{2}$ Nanang Martono, Sosiologi Perubahan Sosial Perspektif Klasik, Modern, Posmodern, dan Pos Kolonial, (Jakarta: Raja Grafindo Persada, 2012), hlm. 6-7

${ }^{3}$ Adalah salah satu staf pengajar di Fakultas Ekonomi-Universitas Indonesia, yang juga dipercaya sebagai salah satu staf khusus Presiden dibidang ekonomi.

${ }^{4}$ Firmanzah, Mengelola Partai Politik, Komunikasi dan Possitioning Ideologi Politik di Era Demokrasi, (Jakarta: Yayasan Obor Indonesia, 2008), hlm. 22-23.

$80 \mid$ JURNAL LISAN AL-HAL
} 
istilah lain ia menyatakan bahwa politik 'man is by nature a political animal'. Lain lagi dengan Machiavelli, dalam bukunya 'The Prince', menyatakan bahwa politik itu segala usaha dan aktivitas untuk memperoleh dan mempertahankan kekuasaan absolute. Moralitas dan etika bagi Machiavelli hanya bisa efektif ketika mampu merebut dan mempertahankan kekuasaan. Hobbes, dalam Leviathan justru melihat legitimasi kekuasaan politik bukan pada cara mendapatkan kekuasaan, tetapi bagaimana kekuasaan itu digunakan untuk melakukan perlindungan kepada siapa saja yang membutuhkan proteksi atas kekuasaan politik. ${ }^{5}$

Selain pemikir politik tersebut diatas, dalam rentang sejarah pemikiran Islam juga ditemukan beberapa nama yang mampu memberikan warna bagi studi tentang politik, khsususnya politik yang berbasis ke-Islaman. Diantara mereka adalah Ibnu Abi Rabi'6, kemudian disusul Farabi, Mawardi, Ghazali, Ibnu Taimiyyah, dan Ibnu Khaldun. Dalam pandangan Munawir Sjadzali, dari keenam pemikir tersebut memiliki dua ideologi umum dalam gagasan politiknya. Pertama, gagasan dan pendapat mereka tentang pemaknaan politik banyak dipengaruhi oleh pemikiran filsuf Yunani, terutama Plato. Sekalipun satu sama lain diantara mereka tidak sama kadar pengaruhnya. Kedua, pemikiran mereka didasarkan atas penerimaan terhadap ideologi kekuasaan yang ada pada jamannya masing-masing, bahkan sampai pada bagaimana mempertahankan kekuasaan. Perubahan dan reformasi politik dilakukan pada saat kekuasaan berada pada ideologi kekuasaan yang telah diperoleh. Kecuali Farabi yang tetap pada gagasannya yang dianggap utopian, sebagaimana Plato, yaitu pencapaian bagi sebuah masyarakat yang ideal untuk membentuk sebuah komunitas besar "Negara Sempurna". Gagasan Farabi ini hampir tidak mungkin dilaksanakan ditengah gelombang masyarakat yang masih dipenuhi oleh kelemahan. Karena terlalu dominannya pengaruh Plato, gagasan politik Farabi hampir tidak ditemukan warna Islamnya. ${ }^{7}$

\section{Agama dan Ideologi}

Karena pergumulan politik berada dalam interaksi social, maka

5 Ibid, hlm. 48-49.

6 Hidup pasa masa pemerintahan Mu'tashim, putra Harun Al-Rasyid, khalifah 'Abbasyiah yang kedelapan,

${ }^{7}$ Munawir Sjadzali, Islam dan Tata Negar:, Ajaran, Sejarah, dan Pemikiran, (Jakarta: Universitas Indonesia Press, 1993), hlm. 41-42. 
politik akan berhadapan, dan melakukan relasi dengan berbagai 'institusi lain'. Dalam kajian makalah ini, maka agama akan menjadi relasi persinggungan dengan dunia politik. Termasuk bagaimana persinggungan politik dengan agama ditengah munculnya berbagai macam bentuk ideologi. Sebagaimana politik, agama juga melakukan interaksi social ditengah komunitas masyarakat, termasuk ditengah Negara. Banyak konsep agama yang dibangun oleh beberapa pemikir sosiologi.

Karl Marx (1818-1883) memiliki pokok-pokok pikirannya dalam memandang agama, yang paling populer adalah gagasannya bahwa agama adalah candu bagi masyarakat, yang memiliki ideologi - ideologi memberikan hiburan yang sifatnya sesaat. Karena sifatnya yang sementara itu, agama disandingkan dengan obat yang bisa membius manusia. Agama tidak bisa memberikan tawaran solusi untuk menyelesaikan permasalahan yang bersifat lama. Agama juga dianggap sebagai satu kesatuan yang memberikan legitimasi penderitaan dan kesengsaraan dunia. Agama, bahkan dipakai untuk memberikan legitimasi kekuasaan bagi kelas-kelas sosial. Karena kepatuhan terhadap kelas social adalah kepatuhan kepada Tuhan. Akhirnya, Marx kemudian membuat kesimpulan bahwa agama itu tidak penting kehadirannya. Sehinga harus dihapus. Sebagai tawarannya, Marx kemudian mengajak manusia untuk tidak beragama, alias komunis (atheis) sebagai jalan keluar, karena kebahagiaan hanya bisa diukur dari adanya materi yang diperolehnya. ${ }^{8}$ Konsep Marx ini sebenarnya juga banyak mendapatkan kritik dari berbagai kalangan. Tapi disini tidak dicantumkan, penulis akan mengungkap definsi lain yang lebih elegan bagi keberadaan agama.

Agama adalah aspek kehidupan manusia yang paling universal. Weber dalm melakukan studi agama menyatakan sejauh yang ia ketahui bahwa tidak ada masyarakat manusia yang tidak memiliki 'agama'. Setiap komunitas manusia memiliki konsep tentang tatanan adikodrati, ruh, tuhan-tuhan, atau daya impersonal yang satu sama lain tidak sama. Kepercayaan masyarakat sederhana terhadap hal-hal yang dikatakan tidak azim, tidak masuk oleh sebagian kalangan teoritisi sosiologi itu memberikan dampak atas penyelesaian masalah. Jadi, agama dalam pandangan Weber (sebagai hasil kajin sosiologi bagi masyarakat primitive, atau sederhana) adalah proses keyakinan yang didasarkan terhadap hal-

${ }^{8}$ Bernard Raho SVD, Agama dalam Perspektif Sosiologi, (Jakarta: Obor, 2012), hlm. $19-27$

82 JURNAL LISAN AL-HAL 
hal transenden yang dapat membantu menyelesaikan masalah social. ${ }^{9}$

Selain dua sosiolog diatas, Emil Durkheim (1858-1917) memberikan definisi agama yang lebih elegan bila disbanding dengan Marx, baginya agama adalah ibarat sebuah satu system keyakinan yang harus diimani, diamalkan, dan memiliki sifat yang sacral. Agama dalam pandangan masyarakat itu sendiri dinyatakan sebagai suci, dan tidak duniawi, sekalipun dalam perkembangannya, agama telah banyak dicemari oleh budaya, sebagai akibat dari perilaku pemeluk dan pemuka agama yang melakukan interpretasi. Agama bagi Durkheim juga dinyatakan sebagai perwujudan "kesadaran kolektif dan Tuhan diposisikan sebagai ideologi idealism".10

Selain mereka (teoritisi sosiologi Barat), adalah Harun Nastuion, dalam esay yang berjudul Agama, Kebudayaan, dan Pendidikan, dijelaskan bahwa ada cara pandang yang berbeda antara pemikir Barat yang didasarkan pada pertimbangan rasional, material, dan tidak memperhatikan aspek lain. Maka pemikir (Islam) yang ada di Timur memandang agama sebagai sebuah keyakinan yang diturunkan dari wahyu Tuhan, bukan ciptaan manusia. Oleh karena itu, agama yang mengandung keyakinan-keyakinan terhadap Tuhan tidak bisa disamakan dengan kebudayaan. Agama adalah sesuatu yang memiliki wilayah diluar kebudayaan. Sementara agama bagi Barat dianggap sebagai hasil olah pikir dan renungan manusia, sehingga nilai-nilai agama disejajarkan dengan nilai ekonomi, politik, pengetahuan, susila, dan lain sebagainya. ${ }^{11}$

Dalam pandangan M. Amin Abdullah, agama bukanlah sebuah doktrin yang beku, yang tidak bisa dijamah oleh ideologi sosial, karena agama merupakan seperangkat ideologi nilai yang menyediakan berbagai norma-norma bagi kepentingan masyarakat. Realitas tersebut terjadi dalam perkembangan agama-agama besar; Yahudi, Kristen, dan Islam. Sehingga, ketika perbincangan agama dipersandingkan dengan kapitalis yang telah dianggap sebagai ideologi 'maju' dalam ekonomi, maka pembahasannya tidak akan pernah 'mati', bahkan semakin hangat dan ideologi ${ }^{12}$.

${ }^{9}$ Max Weber, Sosiologi Agama, penerjemah Yudi Santoso, ( Jogjakarta: IRCiSoD, 2012), hlm. 28-33.

${ }^{10}$ I.B. Irawan, Teori-Teori Sosial dalam Tiga Paradigma Fakta Sosial, Definisi Sosial, dan Perilaku Sosial, (Jakarta: Kencana Pernada Media Group, 2012), hlm. 16

${ }^{11}$ Harun Nasution, Islam Rasional, (bandung; Mizan, 1996), hlm. 287-289. Buku ini merupakan kumpulan esai-esai yang ia tulis.

12 M. Amin Abdullah, dalam pengantar Beragama Kapitalisme, Fachrizal A. Halim, 
Sekalipun Marx menolak adanya agama karena dianggap sebagai candu, tetapi ia sebenarnya tetap memberikan satu kajian sosiologinya bahwa diluar yang materi itu ternyata manusia juga menaruh 'kepercayaan' diluar yang bersifat materi. Sehingga agama (sebagai sebuah keyakinan) bila disimpulkan sebagai sesuatu yang memang sebenarnya dimiliki oleh setiap manusia. Karena kehadirannya memberikan dampak social, maka agama selalu menarik para teoritisi sosiologi untuk melakukan kajiannya. Lalu, jika demikian agama berarti sama dengan ideologi? Atau agama adalah yang melandasi ideologi?

Beragam perspektif para teoritisi tentang ideologi. Satu sama lain tidak sama, tergantung sudut pandang, dan latar belakang pemikiran serta obyek penelitiannya. Pembahasan ideology inilah yang akan mewarnai bagaiman politik dan agama melakukan interaksi. Menurut Prof. Dr. Zainudin Maliki dalam melakukan kajian ideologi lebih dahulu melakukan telusur bagaimana persandingan antara ideologi dan proses pembentukan ideologi. Ia mengemukakan bahwa perbedaan antara ideologi dengan ideologi sangat tipis sekali, sehinga para ahli hampir tidak menemukan urgensi untuk membuat perbedaan secara distinktif. Sehingga konsep ideologi oleh banyak para pemikir sering digunakan secara bengantian dengan konsep ideologi dan pandangan dunia, baik dalam ranah pengetahuan social maupun sebagai pengetahuan yang dilihat sehari-hari. Lalu, ia kemudian membuat simpulan bahwa ideologi adalah sebuah bangunan pikiran berupa argument ideologi maupun pandangan dunia yang digunakan untuk melakukan justifikasi atas tindakan yang dilakukan oleh sekelompok orang. ${ }^{13}$

\section{B. Ideologi Politik}

Ada pepatah yang mengatakan bahwa partai politik tanpa ideologi ibarat sayur tanpa garam, tidak ada rasanya kata orang. Tapi, situasi politik Indonesia hari ini, dan mungkin masih terus berjalan sampai masyarakt menginginkan kembali masa lalu yang masih menghormati ideologi sebagai sebuah cara pandang, paradigm dalam ikut membangun tatanan sosial. Perpolitikan di Indonesia hari ini telah membuat hampir

(Magelang: Indonesiatara, 2002), hlm. ix. Lihat dalam "Agama dan Perkembangan Kapitalisme, pada pembahasan Identitas Keberagamaan Masyarakat Kapitalistik, 65 - 73.

13 Zainudin Maliki, Rekonstruksi Teori Sosial Modern, (Yogyakarta: Universitas Gajah Mada Press, 2012), hlm. 20-21.

84 JURNAL LISAN AL-HAL 
semua orang (untuk tidak menyebutkan secara garis besar) tabu untuk membicarakan tema ideologi. Politik telah bergeser ideologi dan konsumerisme. Jangan-jangan orang Indonesia sudah tidak mempedulikan soal enak tidak enak,walaupun tanpa garam ideologi), yang penting bisa membuat isi perut ${ }^{14}$. Lalu apa sebenarnya yang menjadi kajian sejarah perkembangan Ideologi politik itu?

\section{Konseptualisasi Ideologi politik.}

Ideologi, sebagaimana Gramsci dan Rude', menurut Firmanzah dibedakan menjadi dua konsep, yaitu antara ideologi dan inheren disatu sisi dengan ideologi tradisional atau turunan pada sisi yang lain. Konsep ideologi yang pertama muncul sebagai hasil interaksi social dan ekonomi yang terjadi ditengah masyarakat. Sementara konsep ideologi yang kedua merupakan hasil dari sebuah peristiwa sejarah besar yang terjadi pada masyarakat tertentu. ${ }^{15}$ Seperti dijelaskan oleh Zainudin Maliki, bahwa ideologi sesungguhnya hasil sebuah argument yang dibangun oleh sekelompok masyarakat untuk menjustifikasi tindakannya. Ideologi adalah bangunan ide yang dibangun oleh sekelompok social dalam rangka melakukan gerakan perubahan social. Dan, bangunan ide itu (baik dipaksakan maupun dengan kesadaran) diikuti sebagai sarana mencapai tujuan.

Dalam perjalanan sejarah, pemaknaan dan kontektualisasi atas ideologi selalu mengalami pasang surut, sesuai dengan dinamika perkembangan jaman yang terus bergerak ideologi perubahan. Kata 'ideologi' juga telah mengalami evolusi pemaknaannya. Sementara pada sisi lain, kata ideologi menjadi sesuatu yang tabu saat diperbincangkan, apalagi jika dikaitkan dengan sejarah kelam suatu bangsa. Sebenarnya, ideologi tidak selalu identik dengan persandingan politik, meskipun sebagian besar orang mengidentikkan dengan isme tertentu. Dalam ilmu manajemen, ekonomi, psikologi, sosiologi, dan antropologi, dipakai untuk melakukan analisis dalam pelbagai unit.

Firmanzah lebih lanjut menyampaikan bahwa ideologi selalu berkaitan dengan bermacam-macam sifat pemikiran, abstrak, dan konseptual. Sehubungan dengan ideologi memuat gagasan dan ide yang memuat bagaimana sebaiknya dunia ini berjalan. Maka, ketika ideologi akan bertalian dengan konsep politik, jelas gagasan ideologi tersebut

\footnotetext{
${ }^{14}$ Firmanzah, Mengelola Partai Politik, ... hlm. 81

15 Ibid, hlm. 84
} 
berkaitan dengan bagaimana mewujudkan pergantian kekuasaan, baik dalam masyarakat maupun negara, bukan sekedar diskursus pewacanaan. Setelah kekuasaan berada dalam genggamannya, maka ideologi tertentu dengan gagasan dan idenya yang telah terkonsepkan dalam 86deology dipakai untuk melakukan perubahan, sehingga berbagai keinginan perubahan itu diberi muatan-muatan politik, itulah sesungguhnya yang disebut dengan ideologi politik.

Jika pemegang kekuasaan memiliki gagasan dan ide kapitalisme ${ }^{16}$ maka ia akan cenderung membuat kebijakan politik, dan perubahan struktur kekuasaannya dengan ideologi capitalism. Dilain pihak, jika konsep ideologinya berlatar belakang ideologi demokrasi, maka ia juga akan membawa kekuasaan pemerintahannya dengan ide demokrasinya. Termasuk jika ideologinya dikaitkan dengan ide dan gagasan yang dilatarbelakangi agama tertentu, maka ia akan memasukkan konsep keagamaannya dalam pengaturan ketatanegaraannya, apakah agama dijadikan aturan formal maupun hanya dijadikan sebagai muatan nilainilai dalam kehidupan berbangsa dan bernegara. Sekalipun ada beberapa ideologi dan golongan yang tidak melakukan formalisasi ideologi, atau sebaliknya, dengan berdramaturgi ${ }^{17}$ melakukan formalisasi ideologi

16 Tentag konsep kapitalistik, Marx, sebagaimana ditulis oleh Zainudin Maliki, dengan mengutip gagasan George Ritzer, bahwa Marx sesungguhnya berhaluan humanis. Dalam pandangan Ritzer, tidak benar kalau Marx dikategorikan sebagai berhaluan ideologi radikal yang haus akan darah (a bloodthirsty radical ideology). Hatinya merasa terluka ketika Marx melihat kenyataan sosial kaum buruh menderita akibat eksploitasi yang dilakukan dalam sistem kapitalistik. Sehingga, itulah yang mendorong Marx untuk melakukan aksi sosial dengan melakukan prubahan ke arah sistem sosial yang menjung tinggi kemanusiaan. Lihat Zainudin Maliki dalam Rekonstruksi Teori Sosial Modern, (Yogyakarta: UGM Press, 2012), hlm. 146-147. Kapitalisme dalam pandangan Marx adalah sistem ekonomi yang mempekerjakan sejumlah buruh dalam jumlah yang besar, yang hanya memiliki sedikit hak milik, memproduksi berbagai barang komoditas yang memberikan keuntungan dalam jumlah yang berlimpah bagi sedikit kapitalis karena memiliki; komoditas, alat produksi, dan yang paling menyakitkan Marx adalah membayar murah para pekerja, lihat George Ritzer dan Douglas J. Goodman dalam Teori Sosiologi, terj.. Nurhadi, (Yogyakarta: Kreasi Wacana, 2011), hlm. 57-68.

17 Teori dramaturgi dimunculkan oleh Ervin Goffman (1922-182), yaitu melakukan analogi panggung dengan interaksi sosial. Setiap interaksi sosial selalu ada wilayah muka yang parallel dengan apa yang ada didepan panggung dalam sebuah pertunjukkan teater. Ketika aktor berada di panggung dan kehidupan sosial banyak pihak yang memiliki ketertarikan dengan penampilan, kostum apa yang sedang dipakai, dan benda apa saja yang digunakan dalam aski panggung. Selanjutnya, baik panggung maupun interaksi sosial memiliki wilayah belakang, tempat dimana para aktor mempersiapkan diri untuk 
tertetu sekedar untuk meraih dukungan politik, tapi ideologi yang tidak terformulasikan justru yang digunakan dalam tata aturan bernegara.

Seperti dijelaskan Zainudin Maliki, bahwa ideologi dijadikan sebagai gagasan dan konsep ide untuk melakukan tindakan tertentu. Ini tentu membawa dampak pada gagasan dan ide konseptual ideology politik untuk mempertahankan kekuasaan Negara.

\section{Ideologi Politik dan Teori Kekuasaan Negara}

Dalam berbagai literature, bahwa konsep ideologi tidak pernah bebas nilai (value-free). Seringkali konsep ideology dijadikan alat dan instrument untuk meraih tujuan politik individu, ideologi, atau bahkan yang justru digunakan adalah kekuasaan negara. Inilah yang kemudian digunakan sebagian orang untuk mendorong dirinya bergabung dengan suatu ideologi tertentu. Sampai pada tingkat pertaruhan nyawapun dijalani demi membenarkan bentuk kebenaran yang diyakini absolusitasnya.

Sebenarnya, pembahasan mengenai ideologi sangat luas, namun karena persandingan ideologi dengan tujuan politik untuk meraih 'keuntungan' kekuasaan, maka ada pergeseran makna yang lebih luas tentang ideologi menjadi sebuah ideologi politik. Maka menjadi 'berharga' ketika mempersandingkan ideologi politik dengan kekuasaan. Mengenai kekuasaan, Ritzer melakukan penggabungan dua teori, yaitu teori pertukaran dengan analisis jaringan ${ }^{18}$ agar analisis kekuasaannya melampaui analisis dalam hubungan diadik dan proses distribusi kekuasaan. Menurut teori ini, bahwa kekuasaan itu lebih banyak ditentukan oleh sejauhmana menentukan struktur jaringan, terutama ketersediaan koneksitas antar ideology.

Lasswell dan Kaplan, sebagaimana ditulis oleh SP Varma, membuat suatu analisa tentang konsep kekuasaan, yang menurutnya paling rinci. Keduanya menyatakan bahwa konsep kekuasaan merupakan hal yang paling fundamental dalam ilmu politik. Karena proses politik adalah

tampil dalam panggung, termasuk beristirahat. Nah, ketika aktor berada dibelakang atau di luar panggung, maka ia akan menjadi dirinya sendiri, tanpa terikat oleh aturan dan penampilan dalam panggung. Lihat George Ritzer dan Douglas J. Goodman dalam Teori Sosiologi, (Bantul: Kreasi Wacana, cetakan ketujuh 2011), hlm. 234-235. Inilah yang kemudian dijadikan interaksi dunia politik, antara konsep forma ideologi dengan ideologi sesungguhnya yang dipakai dalam arah pergerakan kekuasaan.

18 Mengenai teori jaringan, teroi pertukaran jaringan dan analisis jaringan bisa anda baca pada Ritzer dalam Toeri Sosiologi, hlm. 469-474. 
bertalian erat dengan pembentukan, pembagian, dan penggunaan kekuasaan. ${ }^{19}$ Lasswell, sebagaimana ia sepakat dengan pandangan Catlin bahwa politik selalu memusatkan perhatiannya pada hubungan beberapa orang, asosiasi dan competisi, sehingga disimpulkan dengan membuat pernyataan tentang hasil akhir dari perundingan politik adalah kekuasaan.

Pandangan tentang bagaimana peranan kekuasaan, tulis Varma, ditentang oleh Bertrand Russel yang menyatakan bahwa pemerataan kekuasaan yang dijalankan dengan cara pembagian kekuasaan sebagai prasyarat paling penting bagi kemerdekaan manusia, ketimbang pemerataan atau pun pembagian kesejahteraan. Karena pemusataan kekuasaan negara, apapun ideologinya, akan menghancurkan keberdayaan manusia yang memiliki banyak potensi. Jadi, keterkaitan ideologi politik dengan bagaimana kekuasaan merupakan dua entitas yang tidak bisa dipisahkan. Penggunaan kekuasaan akan melibatkan ideologi politik, karena sejak awal ideology telah diintrodusir untuk kepentingan politik yang bermuara pada pencapaian dan penggunaan kekuasaan.

Zainuddin Maliki, melakukan kajian tentang kekuasaan, ia membuat judul tersendiri dalam 'Sosiologi Politik', dalam bab I ia menjelaskan tentang konstruks dan model pengelolaan kekuasaan, sementara dalam bab II ia membuat judul 'pengelolaan kekuasaan dengan kekerasaan'. Ia membuat suatu telaah, bahwa kajian dan bahasan sosiologi politik ataupun ilmu politik akan 'memaksa' siapapun untuk melakukan kajian tentang kekuasaan. Maka baginya, kekuasaan merupakan konsep yang sangat terbuka, tidak mungkin seseorang membuat suatu pengertian tunggal, karena mendiskusikan kekuasaan berarti harus melakukan telusur terhadap bagaimana karakteristik kekuasaan, darimana dan dengan cara apa kekuasaan diperoleh, termasuk bagaimana membagi (mendistribusi) kekuasaan ketika kekuasaan itu dijalankan. ${ }^{20}$

\section{Relasi Politik dan Agama}

Diatas telah dijelaskan bahwa tujuan dari politik adalah kekuasaan, yaitu kekuasaan terhadap suatu komunitas, khususnya negara. Dan, pembahasan politik juga tidak bisa dilepaskan dari term tentang negara. Maka ketika melakukan kajian relasi politik dan agama, tentu yang

19 SP. Varma, Teori Politik Modern, terj. Mohammad Oemar dkk, (Jakarta: Raja Grafindo Persada, cet. Kesembilan, 2010), hlm. 247.

20 Zainuddin Maliki, Sosiologi Politik; Makna Kekuasaan dan Transformasi Politik, ( Yogyakarta; UGM Press, 2010), hlm. 5 
dimaksud adalah hubungan antara negara dengan agama. Kajian ini lebih mengemukakan tentang bagaimana pandangan dan ideologi tentang hubungan negara dan agama? Adakah hubungan kontradiktif, saling memerlukan, atau malah tidak memiliki keterkaitan sama sekali antara negara disatu sisi, dan agama pada sisi yang lain.

Banyak literature yang membahas kajian relasi agama dengan Negara. Zainuddin Maliki, dengan menguti Donald Eugene Smith dalam bukunya Religion and Political Development, memulai diskursus relasi agama dan politik menyangkut pengelolaan kekuasaan. Dalam pandangan Smith, membuat suatu dikotomi relasi politik dan agama ke dalam tipologi religio-political power organic pada satu sisi, sementara sisi lain ia membuat tipologi sekuler. Dalam perspektif organic, agama dan politik (kekuassan) merupakan satu kesatuan (integrate), karena konsep agama adalah meliputi seluruh aspek kehidupan. Dan, pandangan sekuler mengatakan bahwa agama dan kekuasaan bukan merupakan satu kesatuan, tidak perlu dilakukan relasi, harus dipisahkan, mana wilayah agama dan mana wilayah kekuasaan, hal ini agar kesempurnaan-kesucian agama benar-benar terjaga. ${ }^{21}$

Dalam khazanah politik Islam kontemporer, tidak ada yang tunggal untuk melakukan klaim terhadap pandangan hubungan antara kekuasaan dan agama, sebagaimana yang diungkapkan Smith dalam membedakan wilayah tersebut. Zainuddin Maliki dalam kajian sosiologi politik, terutama menyangkut politk Islam, memfokuskan pada pemikiran politik Ali Abd. Raziq yang memiliki pandangan bahwa agama dengan keuasaan itu terpisah, inti pemikirannya sama dengan paradigm sekuleristik.

Secara garis besar, dalam pemikiran politik Islam, ada tiga tipe relasi politik (kekuasaan) dengan agama, yaitu tipe pertama, hubungan kekuasaan dan agama dalam satu kesatuan, yang dikenal dengan integralistik. Tipe kedua, yang memiliki pandangan bahwa agama dan kekuasaan saling memerlukan, atau dikenal dengan hubungan simbiotikmutualistik, ideologi balik, dan tipe ketiga hubungan yang terpisah, lebih dekat dengan ideologi sekuleristik. Sebenarnya, ada juga yang menambah hubungan instrumental, saling melengkapi, tetapi ini secara substansif mirip dengan mutualistik. Munawir Sjadzali dalam "Islam dan Tata" Negara bukan saja mengungkap hubungan kekuasaan dan agama, tetapi ia merekonstruksi pandangan beberapa kajian politik Islam, yaitu Ibun Abi Rabi', Farabi, Mawardi, Ghazali, Ibnu Taimiyah, dan Ibnu Khaldun. Keenam pemikir kajian politik Islam tersebut oleh Munawir dikategorikan sebagai

${ }^{21}$ Ibid, Zainuddin Maliki, hlm. 45. 
pimikir politik Islam pada jaman klasik dan pertengahan. Sementara, beberapa pemikir politik Islam yang dikategorikan dalam kontemporer diantaranya; Sayyid Jamal al-Din al-Afghani, Muhammad Abudh, Rasyid Ridho,Ali Abd Al-Rasiq, Hasan al-Banna dengan Ikhwanul Muslimin-nya, Abu al-A'la al-Maududi, dan Muhammad Husain Haikal. Pandangan politik mereka, baik klasik, pertengahan, maupun pertengahan tentu dilator belakangi oleh situasi sosio-politik dimana mereka melihat system pemerintahan yang ada, termasuk resiko yang harus diambil ketika tidak sama dengan pandangan politik penguasa pada masanya. ${ }^{22}$

\section{Relasi Agama Dan Negara Dalam Paham Integralistik}

Sebagaimana yang diungkapkan tentang kekuasaan sebagai sarana untuk membentuk masyarakat yang ideal, maka ketika kekuasaan dihubungkan dengan agama menjadi satu kesatuan. Karena masyarakat yang adalah masyarakat yang mengamalkan ajaran agamanya ditengha kehidupan masyarakat, bangsa, dan Negara. Untuk itu, agar pola kehidupan masyarakat menjadi sempurna, dalam kekuasaan harus merujuk pada kekuasaan yang bersumber dari ajaran agama, ajaran Tuhan yang Suci.

Dalam pandangan ini, Marzuki Wahid dan Rumadi membuat satu pandangan bahwa paradigm ini berpendapat bahwa wilayah agama adalah wilayah yang mengatur politik dan Negara, karena itu, Negara merupakan lembaga politik, sekaligus lembaga keagamaan. Pemegang kekuasaan pemerintahan (kepala Negara) adalah pemegang wilayah otoritas agama dan politik. Sumber kekuasaan berasal dari Tuhan. ${ }^{23}$ Yang termasuk penganut paradigm relasi ini adalah Syi'ah, hanya saja, bagi terma politik Syi'ah, penyebutan dawlah (Negara) diganti dengan imamah (kepemimpinan). ${ }^{24}$

Al-Maududi dalam kajian teori politiknya menjelaskan bahwa kepercayaan terhadap adanya keesaan Tuhan (tauhid) dan kekuasaan-Nya merupakan landasan bagi system social dan moral yang menjadi tugas kerisalahan para Rasul Allah, itulah yang menjadi satu-satunya titik mula

\footnotetext{
22 Lihat Munawir Sjadzali dalam Islam dan Tata Negara, hlm. 41-189.

23 Marzuki Wahid dan Rumadi, Fiqh Madzhab Negara: Kritik atas Politik Hukum Islam Indonesia, (Yogyakarta: LKiS, 2001), hlm. 24.

24 Untuk melengkapi kajian terma politik Syi'ah, lihat Abu al'A'la Al-Maududi, Khilafah dan Kerajaan, terj. Muhammad Al-Baqir, (Bandung; Mizan, 1990), hlm. 272. Lihat pula, Munawir Sjadzali, Islam dan Tata Negara, hlm. 211-216

90 JURNAL LISAN AL-HAL
} 
filsafat politik Islam. Tidak ada hak bagi siapa saja untuk membuat aturan ideologi atas kehendaknya sendiri, termasuk tidak ada kewajiban untuk mentaati aturan ideologi yang dibuat tanpa melandaskan kepada kedaulatan Tuhan. Jadi, menurut Maududi hak untuk membuat suatu ideologi hanya berada pada kehendak ideologi yang dibuat oleh Tuhan. Bahkan Nabi pun juga tidak punya hak untuk memerintahkan melakukan dan tidak melakukan suatu tindakan atas kemauan sendiri, karena Nabi juga terikat oleh perintah Allah. ${ }^{25}$ Argument yang disampaikan oleh Maududi itu mendasarkan pada al-Qur'an yang menyatakan bahwa:

"Hak untuk menetapkan ideologi itu berada di tangan Allah semata. Allah menyuruh (kamu) untuk tidak tunduk selain kepada-Nya. Itulah jalan hidup atau agama yang lurus.." 26 Selain juga ayat yang menerangkan tentang posisi seorang Nabi: "Saya tidak mengikuti (aturan mana pun) kecuali (aturan-aturan) yang telah diwahyukan kepada saya". 27

Karena sumber kekuasaan itu ada pada Tuhan, maka ideologi politiknya dikenal dengan ideologi teokratik, atau teosentris. Penganut madzhab ini diantaranya adalah Khomeini dan Maududi. Dalam simpulan kajian Munawir, ideologi ini dikelompokkan dalam simpulan pertama sebagai ideologi yang cenderung traditional dan semangat anti terhadap Barat. Mereka berpendirian bahwa Islam itu bukan sekedar agama yang dipahami Barat, tetapi sebagai pola hidup yang memiliki ideologi yang holistic atas segala aspek kehidupan, termasuk kehidupan politik yang tidak bisa dipisahkan dengan arena kekuasaan. Untuk memulihkan kejayaan umat Islam, mereka harus kembali kepada pola kehidupan yang dibangun oleh generasi awal semasa Nabi dan al-Khulafa al-Rasyidun. Karena ke-ekstrimannya kepada Barat, mereka mengajak untuk tidak mengikuti apa yang menjadi pola hidup politik ala Barat. ${ }^{28}$

\section{Relasi Agama dan Politik; Paradigma Sekuleristik}

Menurut ideologi ini, hubungan politik dan agama tidak ada keterkaitan, terpisah. Urusan agama adalah urusan privat, menyangkut keyakinan seseorang, tidak boleh siapa pun mengintervensi urusan pribadi orang, termasuk Negara sekalipun. Ini karena agama itu wilayah

${ }^{25}$ Al-Maududi, Teori Politik Islam, dalam John J. Donohue, John L. Esposito, Islam dan Pembaharuan, alih bahasa Machnun Husein, (Jakarta: Rajawali, 1984), hlm. 465-466

${ }^{26}$ Q.S $12: 40$

27 Q.S. 6: 50 .

28 Ibid, Munawir, hlm. 205. 
yang sangat privat dan transcendental. Bagi Durkheim, dalam agama, ideologi kepercayaan yang merupakan representasi dari suatu hakikat yang ideologi yang juga memiliki relasi dengan ideologi sehingga memunculkan adanya ideologi balik antara yang sacral, kepercayaan, ritual, dan gereja (atau tempat persembahan lainnya, pen.). Pandangan ini mendorong Durkheim untuk menjadikan agama sebagai kesatuan ideologi antara kepercayaan dan praktik yang terintegrate dalam satu komunitas moral yang tunggal, dan bagi Durkheim, komunitas tunggal sebagai tempat ritual praktik agama adalah gereja. ${ }^{29}$

Posisi agama sebagai sesuatu yang ideologi, tentu tidak boleh dicampuri urusan kekuasaan yang penuh dengan konflik kepentingan. Dalam pandangan Hobbes, bahwa tidak mungkin manusia menghindar dari conflict of interest. ${ }^{30}$ Firmanzah bahkan menyebutkan bahwa siapa pun yang terlibat dalam urusan dunia politik tidak akan bisa menghindar dari tiga hal, yaitu: kekuasaan, konflik, dan kepentingan. Untuk itu, agama harus bersih dengan seluruh aspek kepentingan politik. Zainuddin Maliki, sebagaimana kajian pemikiran politik Ali Abd Raziq, yang ia kelompokkan sebagai penganjur ideologi sekuleristik, menuliskan bahwa kekuasaan politik itu butuh dengan justifikasi rakyat, sementara agama adalah produk justifikasi yang bersifat ilahiyyah. Antara justifikasi rakyat dengan justifikasi ilahiyyah tidak boleh dicampur adukkan. Ketika seseorang melakukan perintah agama, maka dia tidak perlu mendapat justifikasi kebenaran tindakan keagamaannya dari kekuasaan politik. Sekalipun Raziq banyak diilhami oleh pemikiran Ibun Khaldun, tetapi dalam sisi ini ia berbeda. Karena Khaldun masih melakukan interelasi politik dengan agama sebagai hubungan yang menginspirasi, ia menyatakan bahwa rezim politik itu juga mengurus segala aspek kebutuhan manusia demi kebahagiaan dunia dan akhirat sehingga perlu 'mendapatkan' justifikasi Tuhan.

Tinjauan relasi politik dan agama dalam paham sekularistik Raziq diawali dari beberapa pertanyaan atas klaim khilafat dan kekuasaan politik Islam; 1) Apakah kekhalifahan memang dibutuhkan? 2) Apakah benar Islam membangun ideologi pemerintahan yang resmi dan baku? Dan 3) Sumber kekuasaan itu diperoleh darimana, apakah dari atas (Tuhan), ataukah dari bawah (rakyat)? Ketiga pertanyaan Raziq sebagai

${ }^{29}$ Ritzer, Goodman, Teori Sosiologi, hlm. 104-105.

${ }^{30}$ Zainuddin Maliki, Sosiologi Politik, hlm. 6.

92 JURNAL LISAN AL-HAL 
suatu asumsi tersebut didasarkan pada situasi politik atas lemahnya lembaga kekhalifahan Islam, terutama di kawasan Eropa Timur yang mengakibatkan ketegangan ideologi aktifis politik Islam. Bagi Raziq, sumber kekuasaan politik itu berasal dari rakyat dengan jaringan kekuasaannya bersifat ascending dan demokrasi. ${ }^{31}$

Dalam pandangan Raziq, bahwa Islam itu posisinya tidak berbeda dengan agama-agama lain di dunia yang tidak boleh dicampuri dengan urusan pemerintahan dan kekuasaan, karena agama hanya mengatur urusan hubungan manusia dengan Tuhannya. Soal tata kelola dalam kehidupan dunia, bermasyarakat, baik dalam bidang politik, ekonomi maupun bidang-bidang lain sepenuhnya biar diserahkan kepada umat. ${ }^{32}$ Karena pandangannya yang terlalu berani dan liberal, Raziq banyak menanggung resiko politik dari penguasa pada masa itu, yaitu dipecat dari jabatannya sebagai hakim syari'ah oleh Majelis Ulama Tertinggi Mesir, dan Al-Azhar juga ikut memberikan sanksi kepadanya dengan menanggalkan sebagai alim. Tetapi, sikapnya itu tidak menyurutkan dirinya untuk tetap teguh pada pemikiran politiknya. ${ }^{33}$

Lebih jauh lagi, Raziq berpandangan bahwa Nabi Muhammad SAW oleh Allah hanya diutus menyampaikan dakwah agama murni tanpa memiliki maksud dan tujuan mendirikan sebuah Negara. Nabi tidak memiliki otoritas duniawi, Negara, ataupun pemerintahan, tidak mendirikan kerajaan atau bentuk lain yang sama dalam arti politik. Dia hanyalah seorang Nabi, sebagaimana nabi-nabi sebelumnya. ${ }^{34}$

Agama, sebagaimana tulis Rumadi dalam sebuah penelitiannya, adalah bagian yang paling asasi dalam kehidupan manusia. Agama itu muncul dan berkembang jauh sebelum adanya konsep Negara, munculnya agama berbarengan dengan sejak adanya manusia itu sendiri, seperti ideologi kepercayaan animism, dinamisme, dan sampai pada agama yang terlembagakan. Maka untuk melakukan relasi agama dan Negara (kekuasaan) bukanlah sesuatu yang mudah. Sehingga agama harus benarbenar ditempatkan pada wilayah yang suci. Negara tidak boleh melakukan

31 Ibid, Zainuddin Mailiki, 48. Lihat diagram matriks yang dibuat oleh Zainuddin dalam menggambarkan perpspektif intelektual muslim dalam melihat hubungan antara agama dan politik pada halaman yang sama

32 Yusdani, Fiqh Politik Muslim: Doktrin, Sejarah, dan Pemikiran, (Yogyakarta: Amara Books, 2012), hlm. 4. Lihat juga Munawir pada Islam dan Tata Negara, 205.

33 Ibid, Zainuddin Maliki, hlm. 50.

${ }^{34}$ Marzuki Wahid dan Rumadi, Fiqh Madzhab Negara, (Yogyakarta: LKiS, 2001), hlm. 29-30. 
intervensi terhadap keberadaan agama, ketika hidup matinya agama ditentukan oleh kekuasaan Negara, maka dalam istilah Antonio Gramsci (1891-1939) adalah bentuk hegemoni Negara terhadap agama. Logika agama adalah kebenaran, suatu tatanan paradigmatic atas realitas social dengan sesuatu yang transcendental. Sementara paradigm Negara (dunia) adalah kekuasaan yang memandang sesuatu dengan kacamata pragmatis, ingin menguasai apa saja yang tampak dalam pandangan Negara tersebut. 35

\section{Relasi Agama Dan Negara; Paradigma Simbiotik}

Ide dasar dibentuknya Negara adalah dalam rangka memberikan kebahagiaan kepada masyarakat, sehingga memunculkan sebuah konsep walfare state, yaitu Negara yang dapat memberikan jaminan kebahagiaan rakyatnya. Negara memberikan perlindungan dan bantuan kepada rakyat dalam mengatasi masalah yang tidak bisa diselesaikan sendiri. Karena itulah Negara harus menjadi pelayan rakyatnya, pengelola Negara harus menjadi public service atas kebutuhan masyarakat. Kebijakan Negara, apapun bentuknya harus memberikan kemaslahatan manusia. ${ }^{36}$

Dalam wilayah Negara memberikan jaminan kemaslahatan rakyat, maka posisinya menjadi dibutuhkan, termasuk dalam tata kehidupan beragama, inilah yang memunculkan paradigm simbiotik. Paradigma ini, sebagaimana disampaikan oleh Dien Syamsudin, berpandangan bahwa agama memerlukan keberadaan Negara, karena dengan Negara agama dapat berkembang. Sementara itu, Negara memerlukan agama karena, dengan agama Negara berkembang dalam wilayah bimbingan moral dan etika ${ }^{37 .}$

Politik dalam pandangan Aristoteles, Plato, Jhon Lokce, Hobbes, dan beberapa pemikir politik muslim, seperti Imam Mawardi dan Ibnu Taimiyah adalah sarana untuk membentuk suatu Negara (masyarakat) yang dikelola dengan suatu pemerintahan yang baik, dilalui dengan landasan moral dan etika, dalam rangka tujuan idealism masyarakat. Sebuah masyarakat yang kondisinya lebih baik dari kondisi sebelumnya, jika hari ini baik, maka hari selanjutnya harus lebih baik, jika kemarin

35 Rumadi, "Agama dan Negara: Dilema Regulasi Kehidupan Beragama di Indonesia", Istiqro', Vol. 04, No. 01 (2005), hlm. 118-124.

${ }^{36}$ Ibid, Rumadi, hlm. 119.

${ }^{37}$ Ibid, Marzuki dan Rumadi, hlm. 26.

94 JURNAL LISAN AL-HAL 
tidak baik maka hari ini harus baik dan sejahtera, begitu seterusnya, selalu terjadi perubahan tatanan social masyarakat yang selalu baik. ${ }^{38}$

Eksponen dari ideologi ini adalah Abu al-Hasan al-Mawardiy dan Ibnu Taimiyyah. Dalam karyanya yang termashur, Al-Ahkam alSulthoniyyah, Mawardi menyatakan, bahwa:

"kemimpinan Negara merupakan instrument yang

dijadikan sebagai misi untuk meneruskan risalah kenabian dalam rangka memelihara agama dan mengatur dunia". ${ }^{39}$

Sementara Ibnu Taimiyyah menyatakan bahwa; "Sesungguhya kekuasaan yang mengatur urusan manusia merupakan kewajiban agama yang terbesar, sebab tanpa kekuasaan Negara, agama tidak akan berdiri tegak". ${ }^{40}$ Kedua pemikir politik Islam tersebut jelas memberikan suatu gambaran yang terang relasi agama dan politik. Itu artinya bahwa kehadiran politik bagi agama adalah sesuatu yang memang diperlukan dalam rangka menjadikan agama sebagai inspirasi dan motivasi dalam mengembangkan kehidupan berbangsa dan bernegara.

Dalam kesimpulan yang dibuat oleh Munawir Sjadzali, ideologi ini dikategorikan sebagai ideologi yang menentang terhadap paradigm integralistik dan sekuleristik. Menurutnya, ideologi ini memiliki sebuah ideologi bahwa agama (Islam) ada seperangkat ideologi dan tata nilai moral serta etika bagi kelangsungan hidup dan kehidupan manusia, termasuk dalam urusan kemasyarakatan dan kenegaraan. Hanya saja, urusan bagaimana mengelola Negara, Islam menyerahkan kepada umat sesuai dengan kondisi masing-masing wilayah Negara, mana yang terbaik dan mampu membawa kemaslahatan umat manusia. Termasuk membenarkan Islam melakukan adopasi terhadap system politik Negara lain, seperti system politik yang digunakan Negara-negara Eropa yang notabene bukan Islam. ${ }^{41}$

\section{Agama dan Politik ditengah Ketidakpastian Ideologi}

Relasi agama dan politik (kekuasaan) selain apa yang saya tulis diatas dengan melakukan kategorisasi menjadi tiga tipa paradigmatic, Zainuddin Maliki membagi menjadi dua yaitu, kekuasan versus agama

38 Lihat Firmanzah, Mengelola Partai Politik, Uakarta: Yayasan Obor Indonesia, 2008), hlm. 47-52 hlm. 5

39 Abu al-Hasan al Mawardiy, Al-ahkam al-Shulthoniyyah, (Beirut: Dar al-Fikr, t.t.)

40 Ibnu Taimiyyah, As-Siyaasah asy-Syar'iyyah, hlm. 162.

${ }^{41}$ Ibid, Munawir Sjadzali, hlm. 205. 
dalam perspektif sekularistik disatu sisi dan ideologi disisi yang lain. Bangunan relasi hubungan agama dan Negara, dengan ideologi politik apapun hampir pasti tidak bisa dilepaskan dengan ideologi yang mendasarinya. Bila ideologi politik suatu Negara yang dilatarbelakangi oleh ideologi kapitalis, kecenderungan penguasanya akan menggerakkan ideologi ekonomi tertentu, sehingga peran agama dalam wilayah Negara menjadi tidak berarti. Karena dalam perjalanan sejarah, agama bisa menjadi ideologi positif dan juga liabilitas politik. Karl Marx, Nietzsche, dan Machiavelli membuat asumsi dari implikasi tesis sekulerisasinya, bahwa kemorosotan peran agama digantikan oleh ideologi modern yang berhaluan kapitalis, agama ditolak individu, dan akhirnya agama dianggap tidak mampu menyelesaikan masalah. ${ }^{42}$

Ideologi yang seharusnya menjadi suatu gagasan dan konsep dalam menerapkan gerakan politik ketika kekuasaan berada ditangannya, karena pengaruh kapitalisme menjadikan peran politik tidak jelas arahnya. Dalam pandangan Firmanzah, dewasa ini budaya politik telah diwarnai oleh budaya jalan pintas. Semangat jalan pintas telah merusak setiap aktivitas politik. Prosedur dan mekanisme yang dibangun dengan landasan ideologi juga mengalami reduksi oleh jalan pintas menempuh suatu kekuasaan ${ }^{43}$. Ketika suasana perebutan kekuasaan politik dalam rangka mengatur Negara sudah sedemikian 'rusaknya', lalu kemanakah peran agama? Benarkah asumsi Marx dan kawan-kawannya? Dan bagaimana pola hubungan ditengah suasana ketidakjelasan ideologi politik?

Diawal sudah ada beberapa pernyataan yang menjelaskan bahwa agama itu seperangkat tata nilai dengan logika kebenaran, bersifat ideologi, mengedepankan moral dan etika. Peran ini akan mengalami gangguan dan tantangan berat, ketika dunia politik sudah tidak lagi mengindahkan nilai dan moralitas agama. Ideologi yang dijadikan dasar dalam pertimbangan perumusan plat form partai menjadi sia-sia dan hanya akan dijadikan dokumen sejarah perjalanan politik saja, ketika jaman sudah berubah.

Implikasi dari kapitalisme (yang dalam permukaan ditentang habishabisan) akan merembet pada dunia politik yang dipenuhi dengan segalanya serba materi. Ideologi, program kerja, nilai dan norma-norma politik, atau yang sering disebut dengan etika politik sudah tidak relevan

${ }^{42}$ Ibid, Zainuddin Maliki, hlm. 58

${ }^{43}$ Ibid, Firmanzah, hlm. 25

96 JURNAL LISAN AL-HAL 
lagi. Maka materialism akan menjadikan 97deology97m. Dalam kajian sejarah filsafat pada abad XIX dan XX, filsafat empirisme telah berkembang lebih pesat menjadi beberapa aliran. Aliran pertama memandang bahwa asal atau hakikat adanya sesuatu adalah berasal dari materi. Sementara pada aliran kedua menganggap bahwa suatu criteria kebenaran ajaran (termasuk ideologi jika sudah dijadikan dalam landasan politik) akan memiliki arti ketika membawa "faedah" dan "manfaat". ${ }^{44}$ Tetapi, filsafat ini hanya dijadikan sebagai ideologi untuk membuktikan hipotesis sebuah kebenaran. Bagaimana dengan dunia politik yang sudah terimbas oleh pragmatism dan materialism.

Sebagai penyebab terjadinya politik jalan pintas, dalam konteks Indonesia hari ini pasca reformasi, terutama pada pemilu tahun 2009, dan beberapa pemilihan kepala daerah adalah karena mereka yang berpolitik tidak dilandasi oleh konsep dan gagasan ideology yang jelas. Berpolitik hanya semata-mata memperoleh kekuasaan. Ini sama dengan pandangan ideologi politik yang dibangun oleh Machiavelli, dan akhirnya akan meningkatkan alienasi politik. ${ }^{45}$

Menurut Zainuddin Maliki, setelah peristiwa tanggal 21 Mei 1998, yaitu mundurnya Soeharto dari kursi presiden, atau orang jawa mengatakan istilah lengser keprabon, maka system politik mengalami perubahan, dari corporatic dan bureaucratic authorian menjadi ideologi politik pluralistic. Sistem politik lama (corporatic dan bureaucratic authorian) tidak memberikan ruang bagi ideologi untuk melakukan partisipasi dalam ikut serta melakukan pembentukan warna politik Negara. Ruang ideologi menjadi wilayah para elite, yang kala itu dikendalikan oleh lembaga kepresidenan, militer, dan para konglomerat, ini yang dinamakan dengan triumvirate. ${ }^{46}$ Akibat dari ideologi politik tersebut Negara menjadi konstrain yang efektif untuk melakukan artikulasi gerakan Islam Politik. Tidak ada jalan bagi Islam Politik untuk melakukan formasi politiknya, karena Negara (penguasa) pasti akan represif. Gambaran situasi politi masa itu, kalangan Islam Politik boleh dikatakan memiliki satu ideology politik yang jelas, yaitu bangunan ideology yang dilandasai oleh semangat agama.

Semangat para ideologi Islam Politik dijaman orde lama dan orde

44 Ragwan Albar, "Pragmatisme dalam Filsafat Kontemporer: Pembacaan atas Pemikiran Charles S. Peirce, dalam M. Faisol dkk, Pemikiran Islam Kontemporer, (Surabaya: Pustaka Idea, 2012), hlm. 10-11.

45 Firmanzah, hlm. 40

46 Ibid, Zainuddin Maliki, hlm. 267-270 
baru dalam rangka memperjuangkan idealism politiknya tergambar secara jelas dalam perjalanan sejarah perpolitikan nasional. Setelah ideologi politik era reformasi, dengan memberikan ruang public semakin lebar untuk melakukan partisipasi politik, akhirnya ideologi sudah tidak penting, baik masyarakat pemilih maupun mereka yang akan dipilih. Lebih-lebih ketika ada putusan Mahkamah Konstitusi yang menerapkan system pemilihan langsung. Maka tidak salah jika Firmanzah mengatakan bahwa berpolitik dalam konteks jaman Indonesia dewasa ini yang penting mendapatkan kekuasaan. Memang harus diakui bahwa intensitas politik yang paling besar adalah memperoleh kekuasaan. Selanjutnya, dengan kekuasaan mereka dapat mengatur pola kekuasaannya dengan sederat konsep dan ide yang mereka susun dalm platform partainya. Tetapi karena tuntutan public semakin hari semakin tidak mengarah pada kepentingan ideologi, maka ideologi baru yang bernama pragmatism dan konsumerisme menjalar dalam wilayah perebutan dukungan politik. Hampir tidak bisa dibedakan mana partai yang berasas Islam, berbasis Islam (umat Islam), dan partai yang berbasis kebangsaan. Semua partai menjadi sama dalam pandangan ideologi, karena yang paling menjadi tujuan utama adalah kekuasaan semata.

Maka untuk meletakkan hubungan agama dan Negara ditengah situasi ketidakpastian ideoligi, agama akan menjadi peran instrumental saja. Agama yang mestinya menjadi tata nilai dan moral dalam politik, berubah menjadi wilayah abu-abu. Yang paling membuat masyarakat emoh adalah ketika agama justru menjadi masalah dalam kehidupan masyarakat, bangsa, dan Negara. Ini ditandai oleh berbagai peristiwa social yang menimbulkan kekacauan masyarakat yang mengatasnamakan gerakan agama.

\section{E. Penutup}

Demikian kajian relasi politik dan agama dalam situasi ketidakpastian ideology. Saya menyimpulkan bahwa tiga paradigm hubungan agama dan politik diatas masih perlu dilakukan kajian lebih detail dan mendalam. Situasi politik nasional yang sudah kehilangan ideologi, namun disisi lain samar-samar menggunakan ideologi yang selama ini 'dibenci', yaitu ideologi kapitalis. Ketika partai dikritik oleh public menerapkan ideologi liberal-kapitalis, atau neo-liberal, mereka tersinggung dengan mengemukakan argument pencitraan lewat public.

Akhirnya, saya tertarik dengan apa yang disampaikan oleh seorang professor pengamat sosiologi ideologi dalam acara Indonesia Layer Club,

98 JURNAL LISAN AL-HAL 
Selasa, 2 April 2013; bahwa Indonesia, setelah perubahan UUD 1945 yang keempat telah menerapkan dua ideologi ekonomi sekaligus, yaitu ideologi kerakyatan sekaligus kapitalis. Ekonomi kerakyatan tercermin dalam pasal 33 ayat (1), sementara ayat (2) sebagai landasan penguasa untuk menerapkan kebijakan ekonomi kapitalis, yaitu dengan tambahan kata 'efisiensi berkeadilan'.

Agama tetap tidak boleh surut ditengah situasi ketidakpastian ideologi, karena konsep agama tetap memerintahkan kepada umatnya untuk tidak putus asa dalam melakukan amar makruf nahi munkar. Nampakpnya para ilmuan atau ulama muslim harus terus bekerja keras untuk melakukan kajian strategis atas pudarnya ideologi dalam penyelenggaraan pemerintahan. Sebab, partai politik sebagai salah satu instrument demokrasi dan 'penentu' pintu masuk melakukan perubahan ideologi kenegaraan harus terus didorong untuk tetap berpegang pada ideologi yang jelas dan linier dengan kebangsaan dan kenegaraan yang telah dibangun oleh para pendiri bangsa ini. Memang, masih ada sebagian para ilmuan dan ulama yang enggan dengan pembicaraan politik praktis, tapi disatu sisi lain mereka mau tidak mau berhadapan dengan kenyataan politik yang mengharuskan "menyelami".

\section{DAFTAR PUSTAKA}

Abu al'A'la Al-Maududi, Khilafah dan Kerajaan, terj. Muhammad Al-Baqir, Bandung; Mizan, 1990

Abu al-Hasan al Mawardiy, Al-ahkam al-Shulthoniyyah, Beirut: Dar al-Fikr, t.t

Bernard Raho SVD, Agama dalam Perspektif Sosiologi, Jakarta: Obor, 2012

Firmanzah, Mengelola Partai Politik, Komunikasi dan Possitioning Ideologi Politik di Era Demokrasi, Jakarta: Yayasan Obor Indonesia, 2008

George Ritzer dan Douglas J. Goodman dalam Teori Sosiologi, terj.. Nurhadi, Yogyakarta: Kreasi Wacana, 2011

Harun Nasution, Islam Rasional, Bandung; Mizan, 1996

I.B. Irawan, Teori-Teori Sosial dalam Tiga Paradigma Fakta Sosial, Definisi Sosial, dan Perilaku Sosial, Jakarta: Kencana Pernada Media Group, 2012

Ibnu Taimiyyah, As-Siyaasah asy-Syar'iyyah,

M. Amin Abdullah, dalam pengantar Beragama Kapitalisme, Fachrizal A. 
Halim, Magelang: Indonesiatara, 2002

Al-Maududi, Teori Politik Islam, dalam John J. Donohue, John L. Esposito, Islam dan Pembaharuan, alih bahasa Machnun Husein, Jakarta: Rajawali, 1984

Marzuki Wahid dan Rumadi, Fiqh Madzhab Negara: Kritik atas Politik Hukum Islam Indonesia, Yogyakarta: LKiS, 2001

Max Weber, Sosiologi Agama, penerjemah Yudi Santoso, Jogjakarta: IRCiSoD, 2012

Munawir Sjadzali, Islam dan Tata Negar:, Ajaran, Sejarah, dan Pemikiran, Jakarta: Universitas Indonesia Press, 1993

Nanang Martono, Sosiologi Perubahan Sosial Perspektif Klasik, Modern, Posmodern, dan Pos Kolonial, Jakarta: Raja Grafindo Persada, 2012

Ragwan Albar, "Pragmatisme dalam Filsafat Kontemporer: Pembacaan atas Pemikiran Charles S. Peirce, dalam M. Faisol dkk, Pemikiran Islam Kontemporer, Surabaya: Pustaka Idea, 2012

Rumadi, "Agama dan Negara: Dilema Regulasi Kehidupan Beragama di Indonesia", Istiqro', Vol. 04, No. 01 (2005),

SP. Varma, Teori Politik Modern, terj. Mohammad Oemar dkk, Jakarta: Raja Grafindo Persada, cet. Kesembilan, 2010

Yusdani, Fiqh Politik Muslim: Doktrin, Sejarah, dan Pemikiran, Yogyakarta: Amara Books, 2012

Zainudin Maliki, Rekonstruksi Teori Sosial Modern, Yogyakarta: Universitas Gajah Mada Press, 2012

Zainuddin Maliki, Sosiologi Politik; Makna Kekuasaan dan Transformasi Politik, Yogyakarta; UGM Press, 2010

$100 \mid$ JURNAL LISAN AL-HAL 
